\title{
TANTANGAN GLOBAL DAN UPAYA MENUJU MANAJEMEN PERGURUAN TINGGIYANG EFISIEN
}

\author{
Mulyono \\ mulyonouin@gmail.com \\ Jurusan MPI FITK UIN Maulana Malik Ibrahim Malang \\ Jawa Timur, Indonesia
}

\begin{abstract}
Globalization challenging blows the life of university, tertiary educational institution that has main activity in high educational conversation with academic activity which commonly has universal concepts and adoptive ability in order to balance with the condition and Indonesia situation. Now days, tertiary educational institution is focused on the real big transformation era and it can not be denied anymore that the university must accept it if want surviving, striving, and developing. Solving those problems, many ideas are explored, such as economic concept and decentralization. The other opinion as the alternative is Enterpreneurial University (EU) that is the university which has entrepreneurship character. Nevertheless, whatever concept and development management strategy of university that has already been tested is able to be applied therefore basically; everything must be based on efficiency principle. This point is an important to build the efficient management in university.
\end{abstract}

Key words: challenging, management, university efficiency

\section{Abstrak}

Globalisasi melahirkan tantangan kehidupan bagi universitas maupun lembaga pendidikan tinggi. Halitu memaksa universitas dan perguruan tinggi untuk mempunyai kegiatan utama dalam pergumulan pendidikan tinggi dengan kegiatan akademik yang umumnya memiliki konsep universal dan kemampuan untuk menyeimbangkan dengan kondisi dan situasi Indonesia. Sekarang ini, lembaga pendidikan difokuskan pada era transformasi yang sangat besar dan tidak bisa dipungkiri lagi bahwa universitas harus menerimanya jika ingin bertahan hidup, berjuang, dan mengembangkan. Memecahkan masalah tersebut, banyak ide dieksplorasi, seperti konsep ekonomi dan desentralisasi. Pendapat lain sebagai alternatif adalah Entrepreneur University (EU) yang merupakan universitas yang memiliki karakter kewirausahaan. Namun demikian, konsep dan strategi pengembangan manajemen universitas apa yang telah diuji mampu diterapkan; semuanya harus didasarkan pada prinsip efisiensi. Hal ini merupakan penting untuk membangun manajemen yang efisien di universitas.

Kata kunci: tantangan, manajemen, efisiensi universitas

\section{Pendahuluan}

Pernyataan Heracleitus bahwa "semua berubah, tidak satupun yang tetap (all is change, nothing is permanent)" yang dibuat pada tahun 513 SM hingga kini tetap dijadikan rujukan oleh banyak penulis manajemen modern seperti Peter Drucker dan Michael Porter (Turner, Grude, \& Thurloway, 1996: 3). Meskipun pernyataan tersebut telah berusia lebih dari 2500, tahun namun hingga kini masih diakui, bahkan diperkirakan hal tersebut akan tetap berlangsung sampai akhir zaman kehidupan dunia dengan seluruh kebudayaannya.

Seperti halnya kehidupan manusia, perubahan-perubahan akan selalu terjadi, demikian pula kehidupan di dunia organisasi. Bagi organisasi hanya ada satu kepastian yaitu kesediaan kita terlibat 
dalam perubahan dan konsekuensinya adalah masyarakat harus mampu mengelola perubahan. Kirkpatrick (1985:9) menekankan bahwa tidak ada alasan untuk menarik diri (withdrawal) atau membela diri (defensiveness) dari pengaruh perubahan, tetapi justru perubahan tersebut dihadapi untuk mendorong munculnya kreativitas (stimulate the creativity), inovasi, dan perencanaan yang strategis (planning of strategies), sehingga setiap hari muncul gagasan baru dan cemerlang yang sarat dengan optimisme dan dinamisme. Pendapat senada dinyatakan oleh Magginson (198:437) dalam konteks manajemen, perubahan justru diharapkan menjadi bagian dari warna kehidupan sehari-hari. Dari sisi pandang teori organisasi memberikan argumentasi bahwa semua organisasi - besar dan kecil, swasta maupun pemerintah - dipengaruhi oleh perubahan. Lebih lanjut Kartikowati (2005: 546-547) menekankan bahwa tidak satupun cara untuk menghindari perubahan. Itulah sebabnya, mereka yang berada pada posisi strategis di organisasi harus mengetahui bagaimana bereaksi terhadap perubahan agar tidak gagal menghadapi perubahan.

\section{Tantangan global}

Demikian pula kehidupan dan peran perguruan tinggi, sebagai institusi pendidikan tinggi, dipengaruhi oleh berbagai perubahan yang terjadi baik dalam tataran makro maupun mikro. Hal ini tidak saja di Indonesia tetapi juga melanda hampir seluruh perguruan tinggi di dunia. Pada tataran makro, setidaknya, terdapat tigapengaruh global yang menjadi tantangan pada kehidupan perguruan tinggi.Pertama, hasil-hasil penemuan di bidang teknologi yang berlangsung, patut segera disikapi dengan kemampuan perguruan tinggi mengikuti dan mengejar temuan teknologi tersebut. Kedua, pengaruh globalisasi (komunikasi, misalnya) yang melanda seantero dunia sesungguhnya telah meciptakan peluang tetapi sekaligus dapat menjadi ancamanbagi perguruan tinggi. Perubahan ini memberi peluang perguruan tinggi memperluas segmen pasar hingga ke luar batas negara tetapi sekaligus dapat menjadi ancaman jika disikapi dengan masih menggunakan strategi pasar konvensional. Ketiga, permintaan masyarakat yang terus meningkat akan tersedianya pendidikan tinggi merupakan pertanda perubahan yang signifikan, patut diimbangi dengan kemampuan perguruan tinggi dalam menyediakan pendidikan yang lebih bermutu. Untuk itu para pengelola perguruan tinggi dituntut agar lebih memperhatikan faktor transparansi manajemen, menerapkan desentralisasi atau sentralisasi, sistem kologial atau line management, dan perubahan proses pembelajaran dari teaching ke learning.

Perubahan pada tataran makro maupun mikro ini telah mengilhami dan memacu para pengelola perguruan tinggi mencari terobosan yang menurut mereka tepat dan mengambil keputusan yang menantang (challenging). Masing-masing perguruan tinggi mengambil keputusan dan langkah yang tepat, sesuai dengan tingkat tantangan perubahan yang dihadapi dan kemampuan sumber dana yang dimiliki(Kartikowati, 2005: 547). Sebagai contoh adalah Universitas Sumatera Utara (USU) di Medan, Sumatera Utara yang menetapkan visi dan misi dengan menetapkan USU menjadi universitas yang berorientasi kepada industri - to become a university for industry (Lubis, 2002: 8). Sedangkan Universitas Negeri Jakarta (UNJ) menciptakan slogan "menciptakan pemimpin masa depan" (building future 
leader) yang selalu mewarnai kultur aktivitas kehidupan kampus UNJ (Sutjipto, 2004: 4). Sementara UIN Malang menetapkan visi untuk melahirkan figur Ulama yang Intelek Profesionaldan atauIntelek Profesional yang Ulama'yangdisebut sebagai generasiUlul Albab serta menuju universitas sebagai Pusat Unggulan (Centre of Excellence) dan Pusat Peradaban Islam (Centre of Islamic Civilization).

Dampak globalisasi begitu deras menerpa kehidupan perguruan tinggi yang memiliki kegiatan utama dalam bidang pendidikan tinggi dengan kegiatan akademik yang umumnya mempunyai konsep-konsep universal dan aplikasinya memerlukan kecermatan dan kemampuan adaptif agar serasi dengan kondisi, situasi Indonesia (Mansoer: 1994:98).

Perguruan tinggi saat ini tengah dihadapkan pada masa transformasi besar-besaran. Hal ini tak dapat dipungkiri lagi perguruan tinggi harus menghadapinya, jika ingin tetap hidup, maju dan berkembang. Untuk mengatasi keadaan tersebut sejumlah gagasan dikemukakan, seperti konsep otonomi dan desentralisasi. Satu gagasan lainnya sebagai alternatif adalah enterpreneurial university (EU), yaitu perguruan tinggi yang berkarakter entrepreneurship/wiraswasta. Tentunya apapun konsep dan strategi manajemen pengembangan perguruan tinggi yang telah diujicobakan maupun diterapkan maka pada dasarnya semua harus berlandaskan pada prinsip efisiensi. Hal inilah pentingnya membangun manajemen perguruan tinggi yang efisien di era global ini.

\section{Pentingnya efisiensi dalam manajemen perguruan tinggi}

Dampak globalisasi terhadap lingkungan kehidupan berupa iptek dan ipoleksosbud hankam, pada gilirannya mendesakkan pula pengaruhnya pada perguruan tinggi. Merelevankan hasil/produk perguruan tinggi (berwujud lulusan, penelitian, kegiatan pengabdian/pelayanan masyarakat) dengan tingkat kemajuan pembangunan, memaksa perguruan tinggi mengefisienkan dan mengefektifkan organisasi dan program-program yang dikembangkannya.

Perguruan tinggi yang maju,sesungguhnya tidak cukup hanya berperan aktif menjawab tantangan kebutuhan industri, dunia bisnis dan masyarakat hari ini saja, tetapi seharusnya berperan proaktif merekayasa keperluan masyarakat yang diperkirakan terjadi di masa datang. Dengan demikian, hubungan timbal balik antara perguruan tingi dengan masyarakat pengguna (pemerintah, bisnis, industri dan lembagalembaga masyarakat lainnya) harus dijalin agar terjadi kesesuaian, keserasian dan kesinambungan ketersediaan tenaga kerja yang dibutuhkan.

Menjadikan perguruan tinggi mampu memenuhi tuntutan (demand) masyarakat (mencapai efisien-eksternal) dan sekaligus menunjang perkembangan keperluan (needs) masyarakat kedepan maka perguruan tingga harus membuat dirinya efisien dalam organisasi dan kegiatan (efiensi-internal).Kemenristekdikti menetapkan kebijakan bahwa di bidang pendidikantinggi harus dicapai peningkatan pada tujuh sasaran yaitu:

(1) Relevansi tujuan dan sasaran, dalam arti derajat kesesuaian antara tujuan dan sasaran perguruan tinggi dengan aspirasi semua pihak yang berkepentingan serta dengan keperluan nyata masyarakat, industri dan Pemerintah. 
(2) Efisiensi, dalam arti derajat kehematan dalam penggunaan sumberdaya untuk mencapai tujuan dan sasaran (keterkaitan antara masukan proses).

(3) Produktivitas, dalam arti kuantitas keluaran (dalam hal ini hasil, karena dampak sukar dikuantifikasi) diperhitungkan terhadap satuan sumberdaya tertentu yang digunakan (seperti: lulusan per satuan waktu; penelitian yang dipublikasi, per staf akademik yang berkualifikasi tertentu; konsultasi pada industri per satuan waktu dan lain-lain yang menunjukkan keterkaitan antara proses dan keluaran).

(4) Efektivitas, dalam arti derajat kesesuaian antara tujuan dan sasaran dengan keluaran (hasil dengan memperhitungkan dampak).

(5) Akuntabilitas, dalam arti pertanggungjawaban perguruan tinggi (pimpinan dan pribadi Sivitas Akademika) mengenai segala sesuatu yang dilakukan dalam fungsi pendidikan, penelitian dan pengabdian kepada masyarakat. Pertanggungjawaban tersebut mengacu kepada : (a) peraturan yang berlaku secara umum (di masyarakat) dan khusus (di lingkungan perguruan tinggi), (b) kejujuran dan kebenaran akademik dan profesi, (c) tata nilai, moral dan etika yang dianut di masyarakat.

(6) Pengelolaan sistem dalam arti kemampuan perguruan tinggi menyesuaikan diri/mengadaptasi diri terhadap perubahan yang terjadi di masyarakat (lingkungan kerja, sosial, ekonomi, budaya dan lainlain).

(7) Suasana akademik atau kesehatan organisasi, dalam arti derajat motivasi dan kepuasan kerja Sivitas Akademika dalam pelaksanaan fungsi pendidikan, penelitian dan pengabdian pada masyarakat (Suparman, tt.).

Meningkatkan mutu pendidikan tinggi, memerlukan dana yang besar, staf pengajar yang berkualitas akademik doktor dibidang yang sesuai, perlengkapan pengajaran yang menunjang dan canggih, penelitian yang kuat dan calon mahasiswa yang cerdas. Tidak kalah pentingnya dari semua komponen tersebut, perguruan tinggi harus mempunyai organisasi dan manajemen yang profesional efisien dan efektif. Bila tidak, komponen yang mahal dan langka seperti disebutkan terdahulu, menjadi tak berfungsi.

Untuk menjadikan manajemen perguruan tinggi efisien adalah pekerjaan pelik dewasa ini. Dikatakan demikian karena dana pendidikan masih terbatas, jumlah dan jenis tenaga ahli masih belum cukup. Anggaran pendidikan Indonesia saat ini belum mencapai $20 \%$ dari APBN/APBD, dana yang relatif kecil tersebut masih dikurangi lagi dengan biaya tak terlihat berupa pemborosan yang bersengaja maupun terpaksa. Sebagai perbandingan, biaya pendidikan Malaysia, Philipina, Korea Selatan, masingmasing $\pm 30 \%$ dari APBN-nya.

Disamping itu budaya organisasi dan manjemen lembaga serta pejabat pendidikan tinggi belum sepenuhnya kondusif bagi upaya peningkatan prestasi dan produktivitas akademik. Profesionalisme juga belum dijadikan acuan dalam mengadakan (merekrut) pejabat-pejabat perguruan tinggi. Semua pejabat perguruan tinggi berasal dari dosen, yang ahli di bidang ilmunya, namun tidak dipersiapkan secara berencana untuk menjadi manajer/pimpinan perguruan tinggi. 
Kecenderungan yang ada selama ini ialah perguruan tinggi memekarkan organisasinya, mempertinggi jenjang hirarki organisasinya yang piramidal, sentralis. Pada hal perkembangan organisasi di dunia maju khususnya dalam perusahaan ialah semakin ramping, flat (mendatar, horizontal) dengan hirarki yang juga mendatar.Kecenderungan organisasi perguruan tinggi yang hirarki menunjukkan arah pengembangan manajemen yang tidak efisien.

Kriteria keberhasilan perguruan tinggi yang dewasa ini dijadikan patokan oleh peraturan yang ada seperti prosentase"angka efisien edukasi" (AEE) yaitu masukkan berbanding lulusan atau populasi berbanding lulusan, tidak mendorongnya untuk peningkatan mutu, tapi lebih tepat sebagai strategi mencapai target. Sistem pengembangan karir belum menunjang peningkatan mutu dosen karena kendala biaya, pola dan jenis pendidikan pasca sarjana dalam negeri yang mahal dan kompleks birokrasinya, sedikitnya peluang untuk meneliti dan dana penelitian, serta sulitnya menerapkan hasil-hasil penelitian dalam wujud pengabdian kepada masyarakat.

Keberadaan yayasan sebagai pembina perguruan tinggi swasta, yang justru tidak dalam binaan pendidikan dan akademik, seringkali menimbulkan berbagai masalah yang berakibat langsung kepada efisiensi manajemen PTS (Perguruan Tinggi Swasta). PTS harus tunduk ke Kemenristekdikti maupun Diktis Kemenag bagi PTKIS (Perguruan Tinggi Keagamaan Islam Swasta) secara akademik, namun secara adminstratif tunduk kepada yayasan. Adakalanya kebijakan administrasi dan keuangan yayasan tidak sejalan dengan tuntutan akademik atau tidak sepenuhnya berorientasi kepada kepentingan akademik.
Penelitian yang kemudian ditindaklanjuti dengan seminar tentang "manajemen perguruan tinggi yang efisien“yang dilakukan oleh Unmer Malang pada 27-28 Juli 1994 telah mendorong pemikiran untuk mengkaji ulang manajemn PTN, PTS, PTIS maupun PTKI. Hasil penelitian tersebut menambah data faktual, bahwa telah terjadi in-efisien dalam manajemen perguruan tinggi di Indonesia.

\section{Tantanganmanajemen tinggi}

Apabila masyarakat kampus menyimak kehidupan perguruan tinggi ada beberapa persoalan utama yang perlu dipecahkan, antara lain: (1) PT berada pada kondisi perubahan yang terus menerus berubah, (2) Terbatasnya sumber-sumber pendanaan, Kebutuhan sarana prasarana modern termasuk pemenuhan teknologi informasi semakin meningkat dibarengi dengan cepat usangnya hasil-hasil teknologi tersebut, (4) Semakin berkurangnya peserta didik yang masuk perguruan tinggi, (5) Tarik ulur dalam diri tenaga akademik antara kepemimpinan kolektif organisasi dan kejayaan individu, (6) Persaingan yang terus menguat antar perguruan tinggi, (7) Pengangguran lulusan perguruan tinggi yang semakin melonjak, (8) Perkembangan perguruan tinggi kalah cepat dengan perkembangan iptek, industri, dan sosial budaya.

Bahkan menurut Chester 0 . McCorkle, Jr dan Sandra Orr Archibald dalam Management and Leadership in Higher Education (dalam Ndraha,1988:125-126) yang mengungkapkan beberapa tantangan yang secara umum dihadapi oleh PT dilihat dari sudut manajemen, yaitu:

1) Semakin terbatasnya anggaran pengelolaan perguruan tinggi yang 
disediakan oleh pemerintah atau donatur, sehingga besar pembiayaan perguruan tinggi langsung dibebankan kepada mahasiswa.

2) Semakin berkurangnya jumlah penduduk berusia 18 tahun di beberapa negara. Pada tahun 1982 misalnya penduduk berusia $18-24$ tahun di Amerika Serikat merosot $25 \%$. Sementara itu jumlah penduduk berusia sama (18-24 th) di negara berkembang jutru sebaliknya, meledak.

3) Perlindungan dan peningkatan mutu institusional perguruan tinggi.

4) Pemeliharaan kebebasan (independence) dan viabilitas sumberdaya financial. Yang dimaksudkan dengan hal ini ialah ketidaktergantungan perguruan tinggi pada belas kasihan pihak lain, dan kemampuan generatif sumbersumber sendiri. Jika pun ada sumber dari luar, hendaknya sumber itu tidak mengikat dan tidak memanjakan.

5) Pemeliharaan sumberdaya manusia, sumberdaya fisik, terutama sumberdaya intelektual.

6) Peningkatan partisipasi aktif setiap kelompok masyarakat perguruan tinggi dan pemeliharaan human relations yang efektif antar warga.

7) Peningkatan efisiensi dan produktivitas.

8) Memperbaiki dan memelihara hubungan baik dengan lingkungan, dan meningkatkan public relations dengan setiap kelompok stakeholders (konsumen, dsb.).

9) Memelihara kepercayaan pihak sponsor, pendukung dan simpatisan.

10) Belajar untuk hidup di dalam ketidakmenentuan (uncertainty).

Di sisi lain, gejala komersialisasi pendidikan tinggi juga akan semakin menggejala dan berkembang di Indonesia yang bukan hanya disebabkan pengaruh globalisasi, tetapi juga merupakan kebutuhan obyektif dari masyarakat. Komersialisasi penelitian, kerjasama perguruan tinggi dengan industri di bidang pelatihan dan penelitian, menuntut adanya perubahan-perubahan ke arah pembaharuan yang tentunya tidak bisa melepaskan diri dari dunia bisnis. Dengan demikian kepentingan terhadap dunia pendidikan akan semakin kompleks, karena tidak hanya dihadapkan pada penyiapan SDM atau pembangunan masa depan, akan tetapi juga dihadapkan pada realitas dunia bisnis yang melingkunginya. Dengan demikian PT tidak bisa untuk bersikap ekslusif, akan tetapi juga harus inklusif terhadap persoalan yang dihadapi untuk mencari jalan keluar berdasarkan pada apresiasi intelektual sebagai sarana mencari alternatif pemecahan masalah.

Di sisi lain, kita tidak menutup mata bahwa jumlah PTS yang menggelembung hingga lebih dari 2000 di seluruh tanah air juga memberi problem tersendiri bagi PTS. Artinya, terjadi perebutan calon mahasiswa dari lulusan SMA antar PTS. Belum lagi ada 57 PTN (Gudat, 2007:20) serta penambahan beberapa PTKIN dan Politeknik di berbagai daerah.

\section{MenujuManajemen PT yang Efisien}

Para pakar maupun praktisi pendidikan tinggi menyimpulkan ada beberapa gagasan yang dapat diyakini akan mengefisienkan manajemen perguruan tinggi dewasa ini antara lain sbb:

1. Organisasi perguruan tinggi dewasa ini, haruslah fleksibel, tidak distandarisasikan secara nasional, tidak rigid, tidak birokratik, tidak memerlukan tangga hirarki yang tinggi. Hendaknya didesain berwujud organisasi matriks, terbuka dan menjunjung tinggi hakekat 
pendidikan. Mengembangsuburkan wewenang berdasarkan profesi dan menghadapi wewenang berdasarkan hukum. Tata hubungan bersifat kolegial bukan hirarkis.

2. Pimpinan perguruan tinggi hendaklah tenaga profesional dalam manajemen atau: university administration, selain harus berkualifikasi akademik atau kadar intelektual tinggi sedapat mungkin harus berpredikat sebagai doktor maupun profesor. Unsur pimpinan perguruan tinggi harus dibantu oleh unsur pelaksana akademik (pengajaran, penelitian dan pengabdian kepada masyarakat) yang juga profesional bermutu. Pelaksana akademik, perlu berpredikat profesor, doktor di bidangnya. Unsur pelaksanaan administrasi, mutlak terdidik, terlatih dalam administrasi perguruan tinggi berbasis ICT. Pimpinan mutlak didukung oleh biro perencanaan dan evaluasi yang berstatus bukan pelaksana administrasi tetapi tenaga profesional dalam bidang perencanaan pengembangan perguruan tinggi.

3. Untuk kendali mutu badan nasional akreditasi perguruan tinggi, perlu diaktifkan dan dikelola secara profesional menurut bidang ilmu. Akreditasi program dijalankan serasi dengan akreditasi lembaga oleh ahliahli di bidang masing-masing fakultas didukung oleh asosiasi profesi. Bila badan akreditasi ini berfungsi baik. Peran Kopertis/Kopertais dapat ditingkatkan dalam satu koordinasi untuk pengendalian dan pembinaan PTN, PTKI dan PTS menjadi satu pola dan satu konsep oleh badan akreditasi.

4. Peraturan perundang-undangan yang mengikat, birokratik, kaku, sentralistik perlu ditinjau dan memberi peluang bagi perguruan tinggi untuk tumbuh berkembang sesuai dengan lingkungan dan tingkat kemampuan. Peraturan perundangundangan berkenaan dengan sistem pendidikan perlu diteliti ulang. Apakah tidak mungkin pendidikan strata satu (S1) dijadikan pendidikan umum (liberal education) dalam wujud "college" yang tersebar luas dan ada dimana-mana di seluruh tanah air. Fakultas atau program pasca sarjana (S2, S3) diasuh hanya oleh sejumlah universitas terbatas saja. Pelaksanaan SKS, perlu dibenahi dan diberi sarana yang memadai dan diasuh oleh tenaga administrasi akademik profesional. Dosen harus benar-benar memahami, ide SKS dan taat asas melaksanakan pendidikan berdasarkan SKS.

5. Pembinaan dosen, perlu dirancang dan dilaksanakan secara kontinu. Dosen tetap yang bermutu tinggi harus dipelihara, dipupuk, didukung dengan biaya dan sarana yang cukup, agar dapat memusatkan konsentrasi kerja pada tugasnya. Peluang untuk mengikuti seminar dalam dan luar negeri, melakukan penelitian, publikasi hasil penelitian atau karya tulis lainnya perlu mendapat bantuan fasilitas dan dana dari perguruan tinggi. Dosen tetap yang menjadi "nucleus"pada suatu jurusan/program studi, haruslah memiliki gelar S3 atau minimal S2(bagi program S1) dalamjumlah minimal (96: 12 sks)yaitu 8 orang (1 orang menangani 12 sks; kurikulum inti program S1_ 96 sks) . untuk melayani kurikulum pembulatan (muatan lokal) yatu $40 \%$ x $160 \%$ _ 64 sks dapat menggunakan dosen luar biasa yang bila mungkin mereka adalah mitra kerja dari praktisi dunia 
usaha atau lembaga pengguna.Tugas dosen berupa beban tatap muka,terstruktur dan mandiri benarbenar

dilaksanakan,diperiksa,direncanakan secara konsisten. Dosen senior/guru besar dibebani tugas dan tanggung jawab langsung kepada mahasiswanya,bukan hanya asisten.

6. Kemampuan manajemenpengajaran(mengelola

kelas,merancang program pengajaran,menilai hasil belajar mengembangkan methode dan teknik mengajar,pengendalian proses belajar mengajar,penggunaan sumber belajar,dsb)harus dimiliki oleh manajer-lini,manajer terdepan dari proses pendidikan (ketua jurusan,sekretaris jurusan,kepalakepala laboratorium,kepala bengkelkerja,kepala perpustakaan,kepalakepala UPT lainnya).Dalam batas tertentu dosen juga dituntut berkemampuan manajemen pengajaran serta dapat melaksanakan penelitian tindakan kelas (PTK) guna meningkatkan kreativitas dan mutu pembelajaran.

7. Untuk kendali mutu manajemen perguruan tinggi perlu mengefektifkan peran dewan penyantun,senat perguruan tinggi,badan

perencanaanpengembangan

perguruan tinggi serta menjalin kerja sama erat dengan asosiasi profesi,konsorsium pendidikan tinggi,mutlak harus berfungsi dan diorganisasikan berdasarkan disiplin ilmu oleh administrator berpengalaman.

8. Dana perguruan tinggi perlu ditingkatkan. Dana bantuan pemerintah/subsidi pendidikan tinggi bagi mahasiswa PTN, PTKI dan PTS hendaknya diatur lebih proporsional. Tunjangan belajar harus diberikan berdasarkan prestasi akademik kepada mahasiswa dari semua Perguruan Tinggi (PTN, PTKI dan PTS) secara merata. Seleksi masuk perguruan tinggi perlu ditata atas standard minimal persyaratan masuk perguruan tinggi. Alokasi dana bagi kegiatan akademik (pengajaran, penelitian dan pengabdian masyarakat) lebih diperhatikan daripada dana untuk fasilitas fisik. Biaya pendidikan berupa pendapatan dosen, harus menjadi perhatian utama.

9. Pembukaan perguruan tinggi baru, perlu dikendalikan berdasarkan persyaratan akademik dan atas perhitungan bidang-bidang ilmu yang diprioritaskan. Program studi dari jenis bidang ilmu yang sudah diasuh oleh perguruan tinggi setempat harus dijadikan pertimbangan pada saat memberi izin program studi yang sama di satu wilayah/daerah. Pertimbangan antara program studi sains dan teknologi dengan program studi sosial, budaya, hukum, ekonomi, kesehatan harus ditata dengan perhitungan yang jelas.

10. Yayasan penyelenggara PTS, perlu diperjelas status badan hukumnya. Organisasi yayasan harus mempunyai unit-unit yang berwenang profesional untuk menangani permasalahan (affair) pendidikan tinggi seperti: akademic affair; business affair (finansial dan administrasi); student personnel affaire; university and community relationship. Badan Pelaksana Yayasan, pengendali PTS yang diasuhnya, haruslah terdiri atas tenaga ahli, professional, dibidang pendidikan. (Dikembangkan dari Mansoer, 1994: 104-105). 
Menghadapi berbagai tantangan global maupun upaya mewujudkan manajemen perguruan tinggi yang efesien maka diperlukan perbaikan pengelolaan perguruan tinggi yakni:Pertama, meningkatkan peran program studi dalam perencanaan dan pengelolaan kurikulum, proses pembelajaran, dan seleksi penerimaan tenaga pengajar (dosen baru). Kedua, adanya mekanisme yang lebih jelas dan transparan mengenai seleksi penerimaan dosen baru dan evaluasi proses pembelajaran. Ketiga, meningkatkan networking dengan perguruan tinggi lain dan dengan dunia industri/bisnis. Keempat, mengurangi unit-unit yang merupakan cost center dan menggabungkannya dengan unit lain sehingga dapat merampingkan struktur organisasi. Kelima, membentuk unit yang mampu mendorong diperolehnya sumbersumber pendapatan baru bagi perguruan tinggi di luar pendapatan dari mahasiswa, misalnya Unit Pengembangan Bisnis Universitas, koperasi maupun usahauasaha ekonomi yang relevan. Keenam, menyediakan fasilitas dan infrastruktur pembelajaran yang meningkatkan pemanfaatan teknologi informasi secara optimal. Ketujuh, orientasi anggaran lebih ditujukan pada peningkatan kualitas sumber daya manusia dan penyediaan fasilitas pembelajaran yang lebih baik, seperti laboratorium dan perpustakaan (Gudat, 2007: 20). Kedelapan, dipilihnya pimpinan perguruan tinggi yang kredibel, ahli dalam manajemen lembaga, memiliki kekokohan wawasan akademik serta memiliki visi masa depan.

Menumbuhkan

kemampuan perguruan tinggi seperti tersebut diatas perlu ditinjau faktor-faktor eksternal di samping faktor-faktor internal perguruan tinggi. Manajemen perguruan tinggi tidak bebas dari lingkungan masyarakat dan lingkungan budaya. Merawat, memelihara dan mengamankan lingkungan adalah satu kemestian. Perguruan tinggi harus mampu menjadi kekuatan moral yang mempertajam penghayatan budaya.Lulusan akan hidup di lingkungan yang mempengaruhi perguruan tinggi dan hendaknya perguruan tinggi mampu juga mempengaruhi lingkungan. Pendekatan kontigensi dalam manajemen prguruan tinggi harus diterapkan.

\section{Penutup}

Dengan jelinya menghadapi tantangan global maupun upaya mewujudkan manajemen perguruan tinggi yang efesien, diharapkan akan mendorong keberhasilan peran-peran penting perguruan tinggi dewasa ini, antara lain: Pertama, menghasilkan lulusan yang sesuai, cocok, secara kualitatif dan kuantitatif dengan kebutuhan masyarakat (pemerintah, swasta dan lembagalembaga lain)sehingga mempunyai peran penting dalam mewujudkan daya saing bangsa. Kedua, merancang kurikulum berdasarkan kompetensi keperluan riil dan proses belajar mengajar, yang ditangani oleh dosen bermutu dalam jumlah yang cukup, perlengkapan yang sesuai dan sumber belajar yang relevan berbasis lingkungan dan IT.Ketiga, menumbuhkan manajemen perguruan tinggi yang efisien (baik efisien internal maupun eksternal) dan dilaksanakan oleh tenaga profesional di bidang manajemen/adminstrasi serta sedapat mungkin juga bidang akuntasi dan kewirausahaan. Keempat, merancang struktur organisasi matriks, "flat", mengurangi tangga hirarki seminim mungkin, mementingkan organisasi fungsi, namun tetap dalam wujud organisasi berdasarkan azas kekeluargaan. Menciptakan budaya organisasi terbuka terhadap pembaharuan, menghormati umpan 
balik.Kelima, menghemat dan mengefektifkan penggunaan sumber dana pendidikan di samping mengembangkan potensi menggali sumber-sumber pendanaan perguruan tinggi yang luas dan kokoh.

Guna mencapai tujuan tersebut pemerintah telah mengeluarkan berbagai kebijakan yang dilandasi oleh satu pemikiran ke arah pengelolaan pendidikan yang memberi keleluasaan kepada lembaga pendidikan, dari TK hingga perguruan tinggi, untuk mengatur dan melaksanakan berbagai kebijakan secara luas; yaitu melalui satu strategi yang disebut School Based Management (SBM) yang lebih populer dengan istilah Manajemen Berbasis Sekolah (MBS), di lingkungan perguruan tinggi sering disebut dengan beberapa istilah: University Based Management (UBM), Badan Hukum Milik Negara (BHMN) yang kemudian lahir istilah baru lagi Badan Hukum Pendidikan (BHP), Perguruan Tinggi Berbadan Hukum (PTBH), Universitas Wiraswasta (University Entrepreneurial), maupun Manajemen Berbasis Kampus (Campus Based Management).

\section{DAFTAR PUSTAKA}

Clark, Burton R. 2001. Creating Entrepreneurial Universities: Organizational Pathways of Transformation; Issues in Higher Education Series. UK: Pergamon.

Lubis, Choiruddin P. 2002. "Мenuju Perguruan Tinggi Sebagai Badan Hukum Milik Negara: Prospek dan Masalah", orasi ilmiah disampaikan pada acara Dies Natalis Unsyiah. Banda Aceh, September 2002.

Suparman, Eman. (Widyaiswara PPPG Tertulis Bidang Studi IPS), Manajemen Pendidikan Masa Depan. http://www.dikti.org/menudikti.ht ml, download 25 Juni 2007.

Mansoer, Hamdan. 1994. Menuju Manajemen Perguruan Tinggi yang Efisien (Ulasan Seminar Nasional di Unmer Malang, 27-28 Juli 1994) dalam Majalah Ilmiah Kampus Ungu. Jakarta Timur: ASMI, Oktober 1994.

Q. Thompson, J. Tyler \& P. Howlett. 1995. Reinventing the University: Managing and Financing Institutions of Higher Education, ed(s) Sandra L.J., New York: John Willey \& Sons, Inc.

Gudat, Sebastianus. 2007. Peningkatan Mutu Pendidikan Tinggi. Harian Surya, Senin, 26 Maret 2007.

Kartikowati, Sri. 2005. Universitas Berkarakter Entrepreneurship: Suatu Pilihan Untuk Universitas yang Melakukan Transformasi dalam Permufakatan Pendidikan ke Arah Kualiti Hidup Serantau (Seminar Pendidikan Serantau UKM-UNRI ke2), Kuala Lumpur: Universitas Kebangsaan Malaysia, Jilid 2.

Sutjipto. 2004. Kebijaksanaan Universitas Negeri Jakarta dalam Mengembangkan Universitas Berbudaya Wirausaha: Tantangan, Permasalahan dan Rencana Ke Depan, Makalah disampaikan pada Lokakarya Pengembangan Manajemen Internal UniversitasNegeri Jakarta, Jakarta, 27-29 Januari 2004.

Ndraha, Taliziduhu. 1988. Manajemen Perguruan Tinggi. Jakarta: PT. Bina Aksara.

The Economist: a Survey of Universities, The Knowledge Factory, Oktober $4^{\text {th }}$, 1997.

Abu Bakar, Usman. 2004. Manajemen Berbasis Kampus: Otonomi dan Desentralisasi Pendidikan, Makalah disampaikan pada Acara TOT Dosen PTAIN se-Indonesia di UIN/dh. IAIN Yogyakarta pada Oktober 2004. 
Wahjoetomo. 1994. Menuju Manajemen Perguruan Tinggi yang Efisien, dalam Universitas Merdeka Malang, Juli 1994, Rumusan Hasil Seminar Menuju Manajemen Perguruan Yang Efisien. 